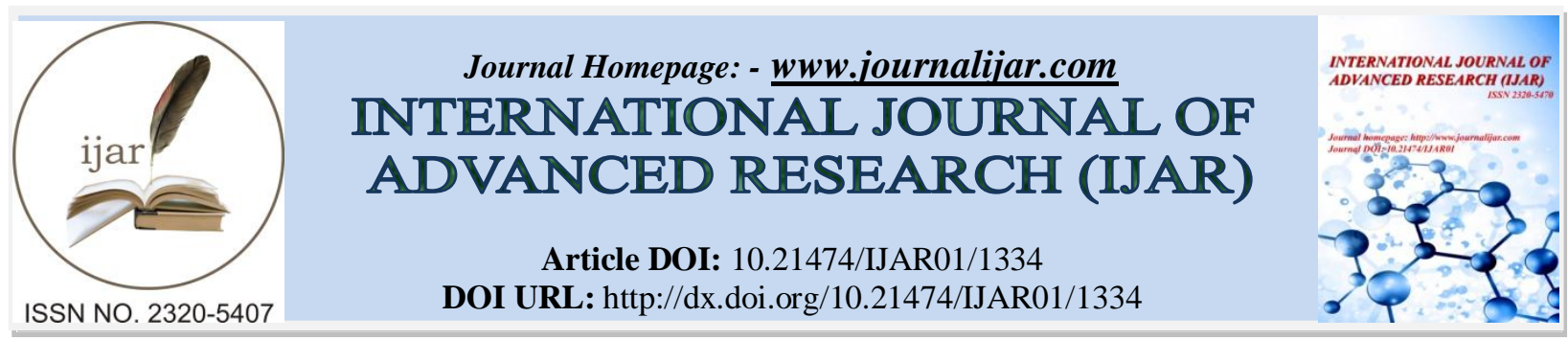

RESEARCH ARTICLE

\title{
EVALUATION OF ANTIBACTERIAL AND THERAPEUTIC POTENTIAL OF HOLARRHENA ANTIDYSENTERICA BARK EXTRACT IN E.COLI CALF DIARRHEA.
}

\author{
Mamta Singh* V.K. Gupta, D.B. Mondal, Mukesh Shakya and D. K. Sharma. \\ Indian Veterinary Research Institute, Izatnagar-243122, India.
}

\section{Manuscript Info}

Manuscript History

Received: 12 June 2016

Final Accepted: 19 July 2016

Published: August 2016

Key words:-

E. coli, Calf, Diarrhea, Holarrhena antidysenterica

\section{Abstract}

In the present study, ethanolic extracts of Holarrhena antidysenterica bark was screened for its antibacterial property against $E$. coli isolates. The antibacterial activity was evaluated by measuring the inhibition zones produced by the extract. Minimum inhibitory concentration (MIC) and minimum bactericidal concentration (MBC) of the ethanolic extract of $H$. antidysenterica exhibiting antibacterial activity. Comparative efficacy of the therapy evaluated by Trial of three different drug regimens i.e. parenteral Gentamicin (Group I), parenteral Gentamicin with oral herbal extracts (Group II) and oral herbal extracts (Group III) were undertaken separately in 5 different calves in each group. The comparative therapeutic evaluation indicated that in case of treatment with parenteral Gentamicin alone and with oral herbal alone the complete recovery took as long as 5 days post treatment where as the other drug regimens (parenteral Gentamicin and oral herbal extract) were equally found effective and bringing faster recovery to near normal by day 3 post treatment. The ethanolic extract of $H$. antidysenterica was equally effective against $E$. coli induced diarrhea in calves. It is therefore concluded that ethanolic extract of $H$. antidysenterica can be used along with Gentamicin in the treatment of E.coli induced calf diarrhea for faster and complete recovery of calves.

Copy Right, IJAR, 2016,. All rights reserved.

\section{Introduction:-}

Diarrhea is one of the most common diseases reported in calves. Microorganism like E. coli, Salmonella, rotavirus, corona virus and Cryptosporidium spp. are capable of causing diarrhea in young calves (Tzipori, 1985; Snodgrass $e t$ al.,1986), among the infectious causes E.coli has been frequently implicated as the primary bacterial cause in calves (Yamamoto and Nakazawa, 1997). Enterotoxigenic E. coli is the most common cause of diarrhea in calves $<21$ days of age. The stem bark which is commonly known as "kurchi" in the Indian subcontinent and as 'conessi bark' in Europe is used in traditional ayurvedic medicine to treat dysentery, especially amoebic dysentery (Bhutani, 1984). Bark of Holarrhena antidsenterica is used in Ayurveda as an anti-microbial, anti inflammatory and analgesics (Kirtikar et al., 1994; Warrrier et al., 1994; Sharma et al., 2004).Various parts of $H$. antidysentrica have been reported to possess antibacterial property (Ganpathy et al., 2008). H. antidysenterica is an herbal drug used in Unani and Ayurvedic system of medicine. The antibacterial and antidiarrheal properties of $H$. antidysenterica have been well documented. The bark has been reported to possess astringent and antidiarrheal properties (Chopra et al., 
1982). So in the present study the therapeutic efficacy of ethanolic extract of $H$. antidysenterica bark against $E$. coli induced diarrhea in calves was evaluated.

\section{Materials and methods:-}

Medicinal plants for screening of antibacterial activity was selected on the basis of scientific literature, ayurveda and indigenous technical knowledge along with their taxonomical identification as $H$. antidysentrica family apocynaceae and assigned number is $2014010228790332 \mathrm{a}$.

\section{Preparation of extract:-}

H. antidysenterica plant was collected from and around Bareilly (U.P.) region. The collected plant parts were washed with clean water and allowed to shade dried for 2-3 weeks. The dried materials were ground to coarse powder. The powder was sequentially extracted with ethanol by soxhlet extraction method as per Okeke et al., (2001). The extract was stored at $4^{\circ} \mathrm{C}$ for further detection of antibacterial activity.

\section{Screening of plant extracts for antibacterial activity:-}

It was carried out by disc diffusion method. Freshly grown bacterial isolate culture $\left(0.5 \times 10^{8} \mathrm{cfu} / \mathrm{ml}\right)$ was inoculated into Muller Hinton Agar (MHA). Plant extract was dissolved in suitable solvent and various concentration (500 $\mathrm{mg} / \mathrm{ml}, 250 \mathrm{mg} / \mathrm{ml}, 125 \mathrm{mg} / \mathrm{ml}, 62.5 \mathrm{mg} / \mathrm{ml}$ and $31.25 \mathrm{mg} / \mathrm{ml}$ ) were prepared by serial dilutions. Empty sterile discs $(6 \mathrm{~mm})$ were impregnated with $25 \mu \mathrm{l}$ of each serial dilution of extract solution. These impregnated disc, now contain different concentration $(12.5,6.25,3.12,1.50$ and $0.78 \mathrm{mg} /$ disc) respectively of extract, with the help of sterile forceps, placed on inoculated surface of agar plate. These were subjected to incubation at $37^{\circ} \mathrm{C}$ for 24 hours, then the diameter of growth inhibition zone was measured.

Determination of minimum inhibitory concentration (MIC) and minimum bactericidal concentration (MBC) of extract were determined as per procedure described by Doughari (2006). For estimating MIC, varying amount of extract $(1.0,2.0,4.0,6.0,8.0,10.0,12.0,14.0,16.0,18.0$ and $20.0 \mathrm{mg})$ was added to eleven different tubes containing two $\mathrm{ml}$ of Mueller Hinton Broth (MHB). To these tubes $10 \mu \mathrm{l}$ of saline suspension of E. Coli whose turbidity was adjusted equivalent to $0.5 \mathrm{McFarland}$ standard was added. A tube containing MHB only was seeded with the test organism serve as control. Tubes were then incubated at $37^{\circ} \mathrm{C}$ for $24 \mathrm{~h}$. After incubation the tubes were examined for microbial growth by observing for turbidity. The lowest concentration of the extract at which no visible growth (turbidity) could be detected by visual inspection was considered the MIC of the extract. To determine the $\mathrm{MBC}$, for each test tube in the MIC determination, a loopful of broth was collected from all the tubes and inoculated on sterile nutrient agar. Inoculated plates were then incubated at $37^{\circ} \mathrm{C}$ for 24 hours. After incubation the concentration at which no visible growth was noted as the minimum bactericidal concentration (MBC).

A dose rate of $10 \mathrm{mg} / \mathrm{kg}$ body weight (Kumar et al.,2011),was given for conducting the in-vivo trial to evaluate the therapeutic potential of ethanolic extract of $H$. antidysenterica .

\section{Therapeutic Trial:-}

For undertaking therapeutic trial studies, fifteen (15) diarrhoeic calves positive for E. coli strain were randomly selected and divided into three (3) groups each consisting five calves.

Test group I diarrhoeic calves received Gentamicin (an aminoglycoside antibiotic) @ 4mg/kg b. wt. as i/m bid for 3-5 days. .

Test group II diarrhoeic calves received Gentamicin @ 4 mg/ b.wt. as i/m bid along with herbal extract @ 10 mg/kg b.wt. orally bid for 3-5 days.

Test group III diarrheic calves received herbal extract @ 10mg/kg b. wt. orally bid for 3-5 days.

In the present study, dehydration due to diarrhea was corrected by i/v administration of isotonic fluids viz. Ringer's lactate solution, Normal saline solution and 5\% Dextrose saline solution in all the groups.

Clinical symptoms like body temperature, appetite, color of feaces etc. of diarrheic calves were noted. The score ( 0 3 ) for faecal consistency, dehydration and depression of each calf were recorded on day 0 and day 7 as per walker et al., (1998). 
Blood were collected on day 0 (before treatment) and day seven (after treatment).Approximately $0.5 \mathrm{ml}$ of whole blood was collected in EDTA vials for estimation of Haemoglobin $(\mathrm{Hb})$ and Packed cell volume (PCV). Seven ml of blood was collected in glass test tubes and processed for separation of serum for biochemical analysis. $\mathrm{Hb}(\mathrm{g} / \mathrm{dl})$ was estimated by cyanomethemoglobin method as per Vankampen and zinglstra, (1961). Packed cell volume (PCV $\%)$ determined as per Coles, (1980). Blood urea nitrogen (BUN) estimated by Diacetylmonosamine method and Serum creatinine estimated by Jaffe's Alkaline Picrate method as per Marsh et al., (1965). Serum total protein (TP) estimated by modified Biuret method and albumin estimated by Dumas method as per Varley et al., (1980). Serum globulin was estimated by subtracting albumin from total protein. Serum albumin globulin $(A / G)$ ratio was estimated by dividing albumin value to globulin value. Serum glucose and serum chloride were estimated according to O'toludine method (Hultman, 1959) and thiocyanate method (Schoenfeld and Lewellen, 1964) respectively. Serum sodium and serum potassium were also estimated (Trinder, 1951; Miller, 1984). The data were statistically analyzed to find the significance of difference between the mean values of different group (Snedecor and Cochran, 1994).

\section{Results and Discussion:-}

During in vitro screening of plant extracts for antibacterial property, ethanolic extract of $H$. antidysenterica exhibited zone of inhibition and therefore considered for further study to find out MIC and MBC. Minimum inhibitory concentration of the $\mathrm{H}$. antidysenterica extract was calculated by broth dilution method. After 24 hours of incubation, turbidity appeared in tubes containing the extract@ 0.5 and $1.0 \mathrm{mg} / \mathrm{ml}$ whereas no growth was observed in all other tubes containing $H$. antidysenterica extract @ 2, 3, 4, 5, 6, 7, 8, 9 and $10 \mathrm{mg} / \mathrm{ml}$. On visual inspection luxuriant growth was observed in the tube not containing any amount of the extract. On this basis the MIC of $H$. antidysenterica extract was considered to be $2 \mathrm{mg} / \mathrm{ml}$. During MBC( Minimum Bactricidal Concentration) trial, good growth was observed on nutrient agar plates streaked with the inoculum taken from serially diluted tubes having $H$. antidysenterica extract @ 0.5 and $1.0 \mathrm{mg} / \mathrm{ml}$ whereas significant reduction in bacterial growth was seen in tube containing $2 \mathrm{mg} / \mathrm{ml}$ (MIC value). No bacterial growth occurred at concentrations of 3-10 $\mathrm{mg} / \mathrm{ml}$. The above finding depicts that $\mathrm{MBC}$ of $H$. antidysenterica extract is $3 \mathrm{mg} / \mathrm{ml}$.

Group I:- On day 0, the diarrhoeic calves of this group had faecal consistency score of $2.62 \pm 0.18$; clinical dehydration score $1.6 \pm 0.25$ and clinical depression score $1.8 \pm 0.37$. Post therapy (on day 7), there was complete clinical recovery with all three clinical scores running to normal. No significant changes in rectal temperature, heart rate and respiration rate of the diarrhoeic calves were recorded before and after treatment which remained in normal range.

As regard to antibiotic therapy (intramuscular Gentamicin) on biochemical profile of diarrhoeic calves of group I, the altered values as recorded on day 0 in respect of number of parameters viz. PCV, TSP, serum creatinine, serum albumin, serum urea nitrogen, serum glucose, serum chloride and serum potassium returned the normal range by day 7 post therapy.

The haemoglobin, A:G ratio and serum globulin in group $\mathrm{I}$, the values were recorded on the 0 were in the normal range. No significant alteration was recorded on the day 7 after the therapy on Day 7 post treatment.

Group II:- On day 0, the diarrhoeic calves of this group had faecal consistency score of $2.68 \pm 0.2$ (almost severe); clinical dehydration score $1.4 \pm 0.24$ (mild) and Clinical depression score 1.6 \pm 0.24 (mild). After therapy on day 7 , there was complete clinical recovery with all three clinical scores running to normal. There were no significant change in rectal temperature, heart rate and respiration rate of the diarrhoeic calves before and after treatment which remained in normal range.

As regard to antibiotic plus herbal therapy (intramuscular Gentamicin and oral herbal therapy) on biochemical profile of diarrhoeic calves of group II, the altered values as recorded on day 0 in respect of number of parameters viz. PCV, TSP, serum creatinine, serum albumin, serum urea nitrogen, serum glucose, serum chloride and serum potassium come towards normal values by day 7 post therapy.

As regards to haemoglobin, A:G ratio and serum gamma globulin in group II diarrhoeic calves values recorded before treatment were in the normal range for the species and these values did not change significantly consequent to muscular Gentamicin and oral herbal therapy on Day 7 of post treatment 
Group III:- On day 0, the diarrhoeic calves of this group had faecal consistency score of $2.46 \pm 0.21$ (almost severe); clinical dehydration score $1.6 \pm 0.12$ (mild) and clinical depression score $1.6 \pm 0.2$ (mild). After therapy on day 7, there was complete clinical recovery with all three clinical scores running to normal.There were no significant change in rectal temperature, heart rate and respiration rate of the diarrhoeic calves before and after treatment which remained in normal range.

As regard to herbal therapy ( on biochemical profile of diarrhoeic calves of group III, the altered values as recorded on day 0 in respect of number of parameters viz. PCV, TSP, serum creatinine, serum albumin, serum urea nitrogen, serum glucose, serum sodium, serum chloride and serum potassium came towards normal values by day 7 post therapy.

As regards to haemoglobin, A:G ratio and serum gamma globulin in group III diarrhoeic calves values recorded before treatment were in the normal range for the species and these values did not change significantly consequent to oral herbal therapy on Day 7 of post treatment. Comparison of the clinical and haemato-biochemical profiles of all the three therapeutic groups depicted in table no.1.

Bark of $H$. antidysenterica is in use for treating diarrhea in traditional/ alternative medicine practices either in India or elsewhere in the world (Kavitha et al., 2009). The MIC and MBC values were found to be 2 and $3 \mathrm{mg} / \mathrm{ml}$ respectively. These findings were similar to the results found by Voravuikuthnchai et al., (2004). The present study was aimed to screen bark of H.antidysenterica with attributed antibacterial property particularly against E.coli invitro test. The antibacterial property of $H$. antidysenterica against pathogenic E.coli strains was confirmed by Voravuthikunchai et al., (2004).

Efficacy of therapeutic study was evaluated on the basis of improvement in the clinical profile and return of the altered haemato-biochemical parameters to the normal value of the species. All the three drug regimens were found effective in treating cases of calf diarrhoea without any mortality. However the comparative therapeutic evaluation indicated that in case of treatment with parenteral Gentamicin alone and with oral herbal alone the complete recovery took as long as 5 days post treatment whereas the other drug regimens (parenteral Gentamicin and oral herbal extract) were equally found effective and bringing faster recovery to near normal by day 3 post treatment itself. The finding of present study were comparable to that of Ramkumar (2012). Hence it is concluded that the ethanolic extract of $H$. antidysenterica can be used along with the antibiotics like Gentamicin for the complete and faster recovery of the calves suffering from E.coli induced diarrhoea. The stem bark used in traditional ayurvedic medicine to treat dysentery, especially amoebic dysentery (Bhutani, 1984). Bark of Holarrhena antidysenterica is used in Ayurveda as an anti-microbial, anti inflammatory and analgesics (Kirtikar et al., 1994; Warrrier et al., 1994; Sharma et al., 2004). 
Table-1- Pre treatment and Post treatment changes in clinical and haemato-biochemical parameters:

\begin{tabular}{|c|c|c|c|c|}
\hline Parameters & Pre/ Post treatment & Group I & Group II & Group III \\
\hline \multirow[t]{2}{*}{ Fecal Consistency score } & Pre-T & $2.62 \pm 0.18$ & $2.68 \pm 0.2$ & $2.46 \pm 0.21$ \\
\hline & Post-T & $00.00 * *$ & $00.00 * *$ & $00.00 * *$ \\
\hline \multirow[t]{2}{*}{ Clinical dehydration score } & Pre-T & $1.6 \pm 0.24$ & $1.4 \pm 0.24$ & $1.6 \pm 0.12$ \\
\hline & Post-T & 00.00 ** & $00.00^{* *}$ & $00.00 * *$ \\
\hline \multirow[t]{2}{*}{ Clinical depression score } & Pre-T & $1.8 \pm 0.37$ & $1.6 \pm 0.24$ & $1.6 \pm 0.12$ \\
\hline & Post-T & $00.00^{* *}$ & $00.00^{* *}$ & $00.00 * *$ \\
\hline \multirow[t]{2}{*}{$\mathrm{Hb}(\mathrm{g} \%)$} & Pre-T & $12.38 \pm 0.168$ & $12.56 \pm 0.06$ & $12.49 \pm 0.063$ \\
\hline & Post-T & $12.52 \pm .048$ & $12.6 \pm 0.11$ & $12.54 \pm .050$ \\
\hline \multirow[t]{2}{*}{ PCV (\%) } & Pre-T & $42.8 \pm 0.8$ & $42.5 \pm 1.59$ & $44 \pm 1.26$ \\
\hline & Post-T & $34.43 \pm 0.8^{* *}$ & $34.6 \pm 0.6 * *$ & $33.72 \pm 1.02 * *$ \\
\hline \multirow[t]{2}{*}{ Total protein (g/dl) } & Pre-T & $7.69 \pm 0.1$ & $7.6 \pm 0.07$ & $7.4 \pm 0.07$ \\
\hline & Post-T & $7.28 \pm 0.14 *$ & $7.12 \pm 0.06^{*}$ & $6.92 \pm 0.13^{*}$ \\
\hline \multirow[t]{2}{*}{ Albumin (g/dl) } & Pre-T & $3.83 \pm 0.09$ & $3.66 \pm 0.06$ & $3.71 \pm 0.17$ \\
\hline & Post-T & $3.24 \pm 0.054 * *$ & $3.35 \pm 0.076^{*}$ & $3.30 \pm 0.064 *$ \\
\hline \multirow[t]{2}{*}{ Globulin (g/dl) } & Pre-T & $4.1 \pm 0.02$ & $3.87 \pm 0.17$ & $3.69 \pm 0.24$ \\
\hline & Post-T & $3.9 \pm 0.03$ & $3.7 \pm 0.29$ & $3.62 \pm 0.52$ \\
\hline \multirow[t]{2}{*}{ A:G ratio } & Pre-T & $0.93 \pm 0.51$ & $0.92 \pm 0.08$ & $0.95 \pm 0.46$ \\
\hline & Post-T & $0.86 \pm 0.9$ & $0.88 \pm 0.03$ & $0.91 \pm 0.4$ \\
\hline \multirow[t]{2}{*}{ Urea nitrogen $(\mathrm{mg} / \mathrm{dl})$} & Pre-T & $27.94 \pm 0.69$ & $26.8 \pm 0.37$ & $27.2 \pm 0.24$ \\
\hline & Post-T & $19.68 \pm 1.00 * *$ & $19.74 \pm 0.38 * *$ & $20.2 \pm 0.47 * *$ \\
\hline \multirow[t]{2}{*}{ Creatinine (mg/dl) } & Pre-T & $1.63 \pm 0.07$ & $1.66 \pm 0.03$ & $1.68 \pm 0.05$ \\
\hline & Post-T & $0.77 \pm 0.05^{* *}$ & $0.78 \pm 0.06^{* *}$ & $0.8 \pm 0.03 * *$ \\
\hline \multirow[t]{2}{*}{ Glucose $(\mathrm{mmol} / \mathrm{L})$} & Pre-T & $41.47 \pm 1.52$ & $43.21 \pm 1.63$ & $42.63 \pm 2.43$ \\
\hline & Post-T & $72.81 \pm 1.39 * *$ & $70.62 \pm 2.94 * *$ & $67.17 \pm 3.87 * *$ \\
\hline \multirow[t]{2}{*}{ Sodium (mmol/L) } & Pre-T & $109.37 \pm 2.87$ & $110.63 \pm 1.38$ & $109.55 \pm 1.05$ \\
\hline & Post-T & $140.34 \pm 2.13^{* *}$ & $141.4 \pm 2.15^{* *}$ & $136.42 \pm 1.43^{* * *}$ \\
\hline \multirow[t]{2}{*}{ Potassium (mmol/L) } & Pre-T & $5.22 \pm 0.05$ & $5.41 \pm 0.07$ & $5.14 \pm 0.17$ \\
\hline & Post-T & $4.23 \pm 0.09 * *$ & $4.3 \pm 0.08 * *$ & $4.45 \pm 0.16^{*}$ \\
\hline \multirow[t]{2}{*}{ Chloride (mmol/L) } & Pre-T & $94.06 \pm 2.17$ & $96.35 \pm 1.5$ & $94.86 \pm 1.74$ \\
\hline & Post-T & $101.49 \pm 1.57 *$ & $102.52 \pm 1.38^{*}$ & $101.73 \pm 1.87 *$ \\
\hline
\end{tabular}

\section{Summary:-}

Results obtained in the present study revealed that the ethenolic extracts of bark of Holorrhena antidysenterica possess potential antibacterial activity against $E$. coli. Our finding supported the ethno medicinal claim that Holarrhena antidysenterica possess potential antibacterial activity against $E$. coli and effective in diarrhea. Hence it is concluded that the ethanolic extract of $H$. antidysenterica can be used along with the antibiotics like Gentamicin for the complete and faster recovery of the calves suffering from E.coli induced diarrhea.

\section{Acknowledgement:-}

The authors are thankful to the Division of Veterinary Medicine and Director of Indian Veterinary Research Institute, Izatnagar (U.P.) India for providing necessary facilities to carry out this work.

\section{Competing interests:-}

The authors declare that they have no competing interests. 


\section{Reference:-}

1. Bhutani, K. K. (1984). Proceedings of National symposium of allied biotechnology of medicinal, aromatic and timber yielding plants, University of Calcutta, India, p. 387

2. Chopra, R. N., Chopra, I. C., Handa, K. L. and Kapur, I. D. (1982). Chopras Indigenous drugs of India. Academic Press, New Delhi, India, p.342. Indian J. Chem. 20B: 62.

3. Coles, E.H. (1980). Veterinary clinical pathology, $3^{\text {rd }}$ edition. W.R. Sounders company. London.

4. .Doughari, J.H. (2006). Antimicrobial activity of Tamarindus indica L. Trop.J. Pharm. Res. 5(2):597-603

5. Ganapathy, P.S.S., H.V. Sudeep, S. Padmalatha Rai and Y.L. Ramachandra, (2008). Screening of crude extracts ofHolarrhena antidysenterica wall. against clinically important pathogenic strains. Med. Aromatic Plant Sci. Biotechnol., 2: 68-71.

6. Hultman, E. (1959). Rapid specific method for determination of aldosaccharides in body fluids. Nature. 183: 108-109.

7. Kavitha, D. and Niranjali, S. (2009). Inhibition of enteropathogenic Escherichia coli adhesion on host epithelial cells by Holarrhenaanti dysenterica wall. Phytother. Res. 23:1229-1236

8. Kirtikar, K. R. and Basu, B. D. (1994). Indian Medicinal plants, Dehradun, Shiva offset press; pp. 1707-1709.

9. Kumar A, Gupta V K, and Vihan, V.S. (2011). Development of herbal antidiarrheal for goat. CIRG Annual report.

10. Marsh, W.H., Fingerhut and H. Miller, (1965). Non protein nitrogen, urea, urates, creatinine and creatinine. In practical clinical biochemistry. $5^{\text {th }}$ (edn), William Heinemann, Medical book ltd, London, PP: 460.

11. Miller,W.G. (1984). Eletrolytes In: Clinical Chemistry Theory, Analysis, and Correlation, Kaplan, L.A and Pesce A.J (Eds.), CV Mosby,Toronto pp. 1044-1079

12. Okeke, M.I., Iroegbu, C.U, Eze, E,N., Okoli ,A.S. and Esimone C.O. (2001). Evaluation of extracts of the root of landolphia owerrience for antibacterial activity. J. Ethnopharmacol. 78(2-3):119-127.

13. Ramkumar, P. K.(2012). Evaluation of therapeutic potential of plant extracts against e.coli diarrhoea in calves. MVSc thesis, IVRI Deemed University, Izatnagar, India.

14. Schoenfeld, R.G. and Lewellen, C.J.(1964). A colorimetric method for determination of Serum chloride. Clin. Chem. 10(6): 553.

15. Sharma, P. C. Yelen, M. B. and Dennis, T. J.(2004). In database on medicinal plants used in Ayurveda, Vol 2. New Delhi; Central Council for Research in Ayurveda and Siddha, p. 550.

16. Snedecor, G.W. and Cochram, W.G. (1994). Statistical methods, $8^{\text {th }}$ edn. Iowa state university press, USA.

17. Snodgrass, D.R., Terzolo, H.R., Sherwood, D., Campbell, I., Menzies, J.D. and Synge, B.A. (1986). Aetiology of diarrhea in young calves. Vet. Rec. 119: 31-34.

18. Trinder, P. (1951). A rapid method for the determination of sodium in serum. Analyst.76:596-599

19. Tzipori, S. (1985). The relative importance of enteric pathogens affecting neonates of domestic animals. Adv. Vet. Sci. Comp. Med. 29: 103-206.

20. Vankampen, E.J. and Zinglstra, W.G. (1961). Colorimetric determination of haemoglobin. Clinica Chemica Acta. 6: 3588 .

21. Varley, H., Grawlock, A.H. and Bell, M. (1980). Practical biochemistry. Vol.I $5^{\text {th }}$ edn, William Heinmann, Medical book ltd, London, pp: 458-484.

22. Voravuthikunchaia, S., Lortheeranuwatb,A., Jeejub,W., Sririrakb,T., Phongpaichitb,S. and Supawitac,T. (2004). Effective medicinal plants against enterohaemorrhagic Escherichia coli O157:H7, J. Ethnopharmacol. 94 ( 1) 49-54.

23. Walker, P.G., Constable, P.D., Morin, D.E., Foreman, J.H., Drackley, J.K. and Thurmon, J.C. (1998). Comparison of hypertonic saline-dextran solution and lactated Ringer's solution for resuscitating severely dehydrated calves with diarrhoea, J. Amer, Vet. Med. Assoc. 213: 113-22.

24. Warrier, P. K., Nambier, V. P. and Ramankutty, C. (1994). Indian medicinal plant: a compendium of 500 species. Delhi: orient longman. pp.191-194.

25. Yamamoto, T and Nakazawa, M. (1997). Detection and sequences of the enteroaggregative Escherichia coli heat-stable enterotoxin 1 gene in enterotoxigenic E. coli strains isolated from piglets and calves with diarrhea. J. Cli. Microbiol., 35: 223-227. 